\begin{tabular}{llllll|rrr} 
Volume & $12, \quad$ Nomor & $1, \quad$ Mei & 2020, & pp & $159-177$ & Copyright & C 2017 \\
Jurnal & Akuntansi, & Program & Studi & Akuntansi, & Fakultas & Ekonomi, \\
Universitas $\quad$ Kristen & Maranatha. & ISSN & $2085-8698$ & e-ISSN & $2598-4977$.
\end{tabular}

http://journal.maranatha.edu

\title{
Human Resource Accounting Disclosure Perusahaan Manufaktur di Indonesia yang Dipengaruhi oleh Ukuran Perusahaan, Profitabilitas, Leverage dan Umur Perusahaan
}

\author{
Arry Eksandy \\ Fakultas Ekonomi dan Bisnis - Univ. Muhammadiyah Tangerang \\ (Jl. Perintis Kemerdekaan I No.33 Cikokol Tangerang, Banten) \\ arry.eksandy@yahoo.com \\ Riski Ulan Sari \\ Fakultas Ekonomi dan Bisnis - Univ.Muhammadiyah Tangerang \\ (Jl. Perintis Kemerdekaan I No.33 Cikokol Tangerang, Banten) \\ riskiulan4@gmail.com
}

\begin{abstract}
The purpose of this study was to determine the influence of firm size, profitability, leverage and age on Human Resource Accounting Disclosure on manufacturing companies listed on the Indonesia Stock Exchange. The population of this study includes all manufacturing companies listed on the Indonesia Stock Exchange (IDX) for the 2016-2018 period. The sampling technique used purposive sampling technique. Based on predetermined criteria, the sample of 64 companies. The type of data used in this study is secondary data using panel data regression analysis methods. The results of this study indicate that the firm size and profitability had a positive effect on Human Resource Accounting Disclosure, while leverage and age did not affect Human Resource Accounting Disclosure.
\end{abstract}

Keywords: Human Resource Accounting Disclosure, Firm Size, Profitability, Leverage, and Age

\begin{abstract}
Abstrak
Tujuan dari penelitian ini adalah untuk mengetahui pengaruh ukuran perusahaan, profitabilitas, leverage dan umur perusahaan pada Human Resource Accounting Disclosure pada perusahaan manufaktur yang terdaftar di Bursa Efek Indonesia. Populasi penelitian ini mencakup semua perusahaan manufaktur yang terdaftar di Bursa Efek Indonesia (BEI) untuk periode 2016-2018. Teknik pengambilan sampel menggunakan purposive sampling
\end{abstract}


dengan didapatkan jumlah sampel 64 perusahaan. Jenis data yang digunakan dalam penelitian ini adalah data sekunder yang dianalisis menggunakan analisis regresi data panel. Hasil penelitian ini menunjukkan bahwa ukuran perusahaan dan profitabilitas memiliki pengaruh positif terhadap pengungkapan Human Resource Accounting Disclosure, sedangkan leverage dan umur perusahaan tidak mempengaruhi Human Resource Accounting Disclosure.

\section{Kata Kunci: Human Resource Accounting Disclosure, Ukuran Perusahaan, Profitabilitas, Leverage, and Umur Perusahaan.}

\section{Pendahuluan}

Human Resource Accounting Disclosure diperlukan untuk menyediakan laporan keuangan perusahaan yang akurat sebagai acuan pengambilan keputusan (Brummet et al., 1968). PSAK No. 19 menyebutkan bahwa aset tidak berwujud adalah aset non moneter yang dapat diidentifikasi dan tidak mempunyai wujud fisik serta dimiliki untuk digunakan dalam menghasilkan atau menyerahkan barang atau jasa, disewakan kepada pihak lainnya, atau untuk tujuan administratif (Ikatan Akuntan Indonesia, 2009).

Fenomena yang sering terjadi tentang Human Resource Accounting Disclosure biasanya timbul karena adanya bentuk kesalahan dan kelalaian dari subjek manajemen maupun karyawan secara langsung maupun tidak langsung dipengaruhi oleh berbagai faktor, baik internal maupun eksternal. Salah satu kasus Human Resource Accounting Disclosure yang sering terjadi adalah kesalahan kerja pada departemen accounting. Sebagai contoh kesalahan kerja karyawan yaitu lupa dalam menyimpan bukti transaksi seperti kuitansi atau nota. Padahal kuitansi dan nota sangat penting dan dapat menjadi bukti yang valid. Kesalahan pencatatan dan rekonsiliasi, kesalahan yang paling banyak dibuat oleh karyawan yakni tidak mencatat laporan keuangan secara rutin. Dengan tidak mencatat transaksi, laporan keuangan akan menjadi tidak sesuai dengan kondisi perusahaan yang sebenarnya. Pada kenyataannya, laporan keuangan yang valid dapat memberikan informasi sebagai bahan pertimbangan untuk menentukan keputusan atau membuat strategi untuk mengembangkan bisnis perusahaan. Kesalahan matematis dalam berhitung, Kesalahan ini sering terjadi ketika sedang terburu-buru, sehingga tidak dapat mendeteksi kesalahan tersebut. Jika kesalahan berhitung digabungkan dengan kesalahan saat pencatatan dan rekonsiliasi. Maka bisa menjadi kesalahan yang besar pada laporan keuangan perusahaan. Karena kesalahan tersebut tidak diketahui, dan akhirnya bisa menyebabkan masalah yang lebih rumit dalam penyelesaiannya. Kesalahan kerja merupakan salah satu kelalaian pengelolaan SDM. (http://kompasiana.com).

Human Resource Accounting Disclosure belum diatur dalam peraturan Otoritas Jasa Keuangan (OJK). Penelitian terkait Human Resource Accounting Disclosure dapat membantu Otoritas Jasa Keuangan (OJK) dan Ikatan Akuntan Indonesia (IAI) dalam membuat standar Human Resource Accounting Disclosure (Santioso, 2017). Dengan demikian pentingnya penelitian ini dilakukan agar bisa memberikan masukan kepada pihak OJK dan IAI dalam menetapkan standar pengungkapan sumber daya akuntansi yang efektif dan sesuai dengan kondisi setiap perusahaan di Indonesia. Sehingga hal ini d i harapkan dapat memberikan gambaran penyajian laporan keuangan yang valid dan dapat memberikan informasi yang akurat 
sebagai bahan pertimbangan menentukan keputusan atau membuat strategi dalam pengembangan bisnis perusahaan.

Perbedaan penelitian ini dengan penelitian sebelumnya adalah belum pernah dilakukannya penelitian tentang Human Resource Accounting Disclosure pada perusahaan manufaktur di Indonesia yang dianalisis menggunakan regresi data panel. Penelitian tentang Human Resource Accounting Disclosure pada perusahaan manufaktur di Indonesia sudah pernah dilakukan oleh Negariani (2017), akan tetapi metode analisis yang digunakan masih menggunakan regresi linear berganda sehingga belum bias memberikan model analisis yang komprehensif karena regresi linear berganda hanya memiliki satu model penelitian, padahal kegiatan operasional perusahaan manufaktur memiliki tingkat kompleksitas yang tinggi maka lebih tepat apabila menggunakan regresi data panel karena regresi data panel memiliki tiga model penelitian dalam pemilihan model analisis sehingga bias didapatkan hasil yang tepat untuk menganalisis aktifitas bisnis perusahaan manufaktur.

\section{Kerangka Teoritis dan Hipotesis}

\section{Tinjauan Pustaka}

\section{Signalling Theory}

Teori Signal (signalling theory) adalah teori yang dikemukakan oleh Ross (1977). Dalam teori ini dikemukakan bahwa pihak eksekutif perusahaan akan memiliki informasi yang lebih baik dan cenderung untuk memberikan informasi tersebut kepada calon investor. Adanya informasi berupa "berita bagus" yang dimiliki perusahaan terkait dengan prospek dimasa yang akan datang diharapkan dapat meningkatkan harga saham perusahaan. Secara garis besar ketersediaan informasi erat kaitannya dengan signalling theory.

Keterkaitan teori signal dalam penelitian ini terletak pada variabel ukuran perusahaan yaitu perusahaan besar menunjukkan perusahaan mengalami perkembangan sehingga akan memberikan sinyal baik kepada pihak luar seperti para investor yang memberikan respon positif pada perusahaan tersebut. Sehingga perusahaan berukuran besar akan mengungkapkan informasi yang lebih banyak, karena mendapatkan permintaan yang lebih besar dari publik dan para investor untuk mengungkapkan informasi yang lebih lengkap. Dan pada variabel profitabilitas yaitu ketika perusahaan dengan tingkat profitabilitas tinggi, akan menggunakan informasi keuangannya untuk mengirim sinyal kepada pasar. Laporan keuangan yang memiliki tingkat profitabilitas tinggi menunjukkan prospek perusahaan baik, sehingga investor akan merespon positif sinyal tersebut dan nilai perusahaan akan meningkat.Sedangkan kaitannya dengan variabel Human Resource Accounting Disclosure yaitu ketika mendapatkan respon pasar yang baik, perusahaan memberikan sinyal berupa pengungkapan informasi yang lebih luas termasuk Human Resource Accounting Disclosure. Pengungkapan tersebut akan memberikan informasi yang lebih detail bagi pihak luar, sehingga para investor akan semakin yakin dengan dana yang dikelola oleh sumber daya yang berkompeten di perusahaan tersebut.

\section{Agency Theory}

Teori agensi (agency theory) dapat diartikan sebagai hubungan antara agent atau manajemen suatu usaha dan principal atau pemegang saham (Jensen dan Meckling, 1976). Menurut teori ini, baik pemegang saham maupun pihak manajemen lebih cenderung bertindak atas kepentingan mereka sendiri. Hubungan antara pemegang saham dan pihak manajemen sangat memungkinkan untuk terjadinya konfik yang biasa disebut dengan agency conflict. Teori agensi menyatakan bahwa antara pemegang saham dan pihak manajemen mempunyai kepentingan yang berbeda (Jensen dan Meckling, 1976). 
Keterkaitan teori agensi dalam penelitian ini terletak pada variabel leverage ketika tingkat leverage semakin tinggi, principal atau peminjam dana akan lebih ingin mengawasi kinerja perusahaan yang mereka pinjamkan dananya. Biaya pengawasan tersebut dapat disebut monitoring cost. Ketika struktur modal dengan tingkat hutang yang tinggi akan membuat biaya keagenan lebih tinggi, sehingga semakin tingginya tingkat hutang akan mendorong perusahaan untuk meningkatkan pengungkapan SDM perusahaan. Sedangkan pada variabel umur perusahaan, perusahaan yang memiliki umur lebih tua cenderung lebih dipercayai oleh principal atau pemilik modal karena agen lebih berpengalaman dalam mengelola perusahaan tersebut. Sehingga semakin besar informasi SDM yang dapat diungkapkan, kemudian principal sebagai investor akan semakin yakin dengan dana yang dikelola oleh perusahaan yang lebih tua dibandingkan perusahaan yang muda.

\section{Human Resource Accounting Disclosure}

Human Resource Accounting Disclosure adalah proses mengidentifikasi dan mengukur data tentang sumber daya manusia serta mengkomunikasikan informasi ini kepada pihak yang berkepentingan (Al Mamun, 2009). Pada tahun 1973 Accounting Association Committee in Human Resource Accounting mendefinisikan Human Resource Accounting Disclosure sebagai proses identifikasi dan pengukuran data tentang sumber daya manusia dan mengkomunikasikan informasi ini kepada pihak yang berkepentingan. Ini menyediakan informasi tentang biaya sumber daya manusia dan nilai-nilai yang berfungsi untuk memfasilitasi pengambilan keputusan, dan memotivasi para pembuat keputusan untuk mengadopsi perspektif sumber daya manusia (Sackmann et al., 1989).

Ada tiga fungsi dari Human Resource Accounting Disclosure yang diungkapkan oleh Belkoui (1985), yaitu:
1. Sebagai kerangka kerja untuk membantu pengambilan keputusan didalam SDM.

2. Memberikan informasi kuantitatif tentang biaya dan nilai SDM sebagai unsur organisasi.

3. Memotivasi manajer mengadopsi informasi SDM dalam pengambilan keputusan yang menyangkut orang.

Berdasarkan pendapat tersebut dapat disimpulkan bahwa Human Resource Accounting Disclosure dapat diartikan sebagai suatu proses pengukuran dan pelaporan biaya serta nilai manusia sebagai sumber daya organisasi dan pelaporan hasilnya kepada pihak yang berkepentingan.

\section{Ukuran Perusahaan}

Ukuran perusahaan secara umum dapat diartikan sebagai suatu perbandingan besar atau kecilnya suatu objek. Menurut Poerwadarminta (1983) ukuran perusahaan diartikan sebagai "(1) alat-alat untuk mengukur (seperti menjengkal dan sebagainya), (2) sesuatu yang dipakai untuk menentukan (menilai dan sebagainya), (3) pendapatan mengukur panjangnya (lebarnya, luasnya, besarnya) sesuatu". Jika pengertian ini dihubungkan dengan perusahaan atau organisasi, maka ukuran perusahaan (organization size) dapat diartikan sebagai suatu perbandingan besar atau kecilnya usaha dari suatu perusahaan atau organisasi. Dengan demikian ukuran perusahaan merupakan sesuatu yang dapat mengukur atau menentukan nilai dari besar atau kecilnya perusahaan.

\section{Profitabilitas}

Menurut Agus (2010) profitabilitas adalah kemampuan perusahaan memperoleh laba dalam hubungannya dengan penjualan, total aktiva maupun modal sendiri. Sedangkan menurut Hanafi (2009) mengatakan bahwa pengertian profitabilitas adalah kemampuan perusahaan menghasilkan laba dengan menggunakan total aset (kekayaan) yang dipunyai perusahaan setelah disesuaikan dengan biaya-biaya untuk mendanai aset tersebut. Selanjutnya menurut Toto (2011) 
Profitabilitas adalah kemampuan menghasilkan laba. Pengertian laba bisa bermacam-macam, tergantung kebutuhan dan pengukuran laba tersebut.

\section{Leverage}

Leverage merupakan rasio yang menggambarkan kemampuan perusahaan untuk membayar seluruh kewajibannya, baik kewajiban jangka pendek maupun jangka panjang apabila perusahaan dibubarkan. Leverage diukur menggunakan debt to asset ratio dengan cara membandingkan total hutang dengan total aktiva. Semakin besar debt to asset ratio menunjukkan semakin tinggi kemampuan perusahaan dalam memenuhi seluruh kewajibannya baik jangka pendek maupun jangka panjang (Kasmir, 2011).

\section{Umur Perusahaan}

Pengertian umur menurut KBBI (2011) adalah lama waktu hidup atau ada sejak lahir, dan pengertian perusahaan menurut Hery (2012) adalah sebuah organisasi yang beroperasi dengan tujuan menghasilkan keuntungan dengan cara menjual produk kepada pelanggannya. Dengan demikian umur perusahaan adalah lamanya perusahaan beroperasi dimulai dari tahun berdirinya perusahaan tersebut sampai saat ini dalam kegiatan penjualan produk kepada para pelanggan.

\section{Hipotesis}

Ukuran Perusahaan dan Human Resource Accounting Disclosure

Ukuran perusahaan yang besar menunjukkan perusahaan mengalami perkembangan sehingga investor merespon positif dan nilai perusahaan akan meningkat. Aspek penilaian yang biasa digunakan untuk mewakili ukuran perusahaan, diantaranya yaitu total aset, total penjualan, dan kapitalisasi pasar. Semakin besar total aset maka semakin banyak modal yang ditanam, semakin banyak penjualan maka semakin banyak perputaran uang dan semakin besar kapitalisasi pasar maka semakin besar pula perusahaan dikenal dalam masyarakat (Huebla, 2013). Ketersediaan dana dan sumber daya yang besar membuat perusahaan merasa perlu untuk melakukan pengungkapan informasi secara lengkap karena perusahaan berukuran besar mendapatkan permintaan yang besar dari publik akan informasi yang diungkapkan salah satunya adalah informasi Human Resource Accounting Disclosure.

\section{$\mathrm{H}_{1}$ : Ukuran perusahaan berpengaruh positif terhadap Human Resource Accounting Disclosure}

\section{Profitabilitas dan Human Resource Accounting Disclosure}

Menurut Sari (2014) perusahaan yang berprofitabilitas tinggi dengan sukarela akan memberikan informasi terkait sumber daya manusianya sebagai informasi penting dalam pengambilan keputusan karena didukung oleh tersedianya dana yang cukup unuk mengungkapkannya. Maka dengan demikian profitabilitas yang tinggi menandakan perusahaan memiliki dana yang cukup untuk menyampaikan semua informasi penting yang dapat meningkatkan citra perusahaan salah satunya Human Resource Accounting Disclosure

\section{$\mathrm{H}_{2}$ : Profitabilitas berpengaruh positif terhadap Human Resource Accounting Disclosure}

\section{Leverage dan Human Resource Accounting Disclosure}

Perusahaan dengan leverage tinggi mempunyai biaya pengawasan yang tinggi sehingga perusahaan berusaha untuk mengurangi biaya tersebut dengan mengungkapkan informasi lebih banyak (Prasetyo, 2012). Informasi yang diungkapkan salah satunya adalah Human Resource Accounting Disclosure. Karena kreditur akan selalu mengawasi aktivitas dan kinerja perusahaan untuk meyakinkan 
bahwa perusahaan tersebut nantinya dapat memenuhi kewajibannya pada saat jatuh tempo. Dengan demikian, semakin tinggi leverage perusahaan maka semakin luas pengungkapan informasi dalam laporan tahunannya, termasuk pengungkapan mengenai informasi akuntansi sumber daya

\section{$\mathrm{H}_{3}$ : Leverage berpengaruh positif terhadap Human Resource Accounting Disclosure}

\section{Umur Perusahaan dan Human Resource Accounting Disclosure}

Perusahaan yang terdaftar di pasar modal lebih lama memiliki banyak pengalaman untuk mengungkapkan informasi dengan mempertimbangkan reaksi pasar terhadap pengungkapan yang sesuai. Semakin lama perusahaan asumsinya perusahaan akan lebih berpengalaman untuk melakukan pengungkapan termasuk Human Resource Accounting Disclosure (Widodo, 2014).

\section{$\mathrm{H}_{4}$ : Leverage berpengaruh positif terhadap Human Resource} Accounting Disclosure

\section{Metode Penelitian}

\section{Populasi dan Sampel}

Populasi dalam penelitian ini adalah perusahaan manufaktur yang terdaftar di Bursa Efek Indonesia (BEI) periode 20162018. Teknik pengambilan sampel yang digunakan adalah metode purposive sampling. Adapun kriteria pemilihan sampel adalah sebagai berikut:

\begin{tabular}{|l|c|}
\hline \multicolumn{1}{|c|}{ KRITERIA } & JUMLAH \\
\hline $\begin{array}{l}\text { 1. Perusahaan manufaktur yang terdaftar di Bursa } \\
\text { Efek Indonesia selama periode 2016-2018. }\end{array}$ & 168 \\
\hline $\begin{array}{l}\text { 2. Perusahaan yang tidak menerbitkan annual } \\
\text { report dan Laporan Keuangan tahunan secara } \\
\text { lengkap selama periode 2016-2018 }\end{array}$ & $(53)$ \\
\hline $\begin{array}{l}\text { 3. Perusahaan yang menerbitkan Laporan } \\
\text { Keuangan Tahunan tidak menggunakan mata } \\
\text { uang Rupiah. }\end{array}$ & $(23)$ \\
\hline $\begin{array}{l}\text { 4. Perusahaan yang mengalami kerugian selama } \\
\text { periode 2016-2018 }\end{array}$ & $(28)$ \\
\hline $\begin{array}{l}\text { 5. Jumlah perusahaan yang dijadikan sampel } \\
\text { penelitian }\end{array}$ & 64 \\
\hline
\end{tabular}

Perusahaan manufaktur yang telah memenuhi kriteria sebagai sampel penelitian sebanyak 64 perusahaan selama 3 tahun penelitian, sehingga jumlah data yang digunakan dalam penelitian ini sebanyak 192 data.

\section{Definisi dan Pengukuran Variabel}

a. Variabel Independen

Dalam penelitian ini terdapat 4 (empat) variabel independen (bebas), yaitu:

\section{1) Ukuran Perusahaan $\left(X_{1}\right)$}

Ukuran perusahaan yang diukur dengan total aset akan ditransformasikan dalam logaritma natural untuk menyamakan dengan variabel lain karena total aset perusahaan nilainya relatif besar dibandingkan variabel-variabel lain dalam penelitian ini, sehingga terbentuk rumus:

Size $=$ Ln $($ Total Assets $)$

Sumber: Rahayu (2015)

\section{2) Profitabilitas $\left(X_{2}\right)$}

Salah satu indikator rasio profitabilitas adalah Return on Assets (ROA). Hasil pengembalian investasi atau Return on Assets merupakan rasio yang menunjukkan hasil (return) atas jumlah aktiva yang digunakan dalam perusahaan. ROA berfungsi untuk mengukur efektifitas perusahaan dalam menghasilkan laba dengan memanfaatkan aktiva yang dimiliki. Semakin besar ROA yang dimiliki suatu perusahaan, maka semakin efisien penggunaan aktiva, sehingga akan memperbesar laba (Istiani, 2015). Rumus yang digunakan adalah sebagai berikut:

$$
\text { ROA }=\frac{\text { Earning After Tax }}{\text { Total Assets }} \times 100 \%
$$

Sumber: Istiani (2015)

\section{3) Leverage $\left(\mathrm{X}_{3}\right)$}

Salah satu indikator rasio leverage adalah Debt to Assets Ratio (DAR) atau Debt Ratio. DAR merupakan rasio utang yang 
digunakan untuk mengukur seberapa besar aktiva perusahaan dibiayai oleh utang atau seberapa besar utang perusahaan berpengaruh terhadap pengelolaan aktiva (Istiani, 2015). Rumus yang dapat digunakan adalah sebagai berikut:

$$
\text { DAR }=\frac{\text { Total Debts }}{\text { Total Assets }} \times 100 \%
$$

Sumber: Istiani (2015)

\section{4) Umur Perusahaan}

Umur Perusahaan dapat diartikan sama dengan usia listing perusahaan. Sesuai dengan peraturan pada Bursa Efek Indonesia, umur perusahaan dapat diukur mulai pertama kali perusahaan listing di BEI sampai tahun terakhir periode yang dijadikan sampel penelitian.

AGE
$=$ Tanggal penelitian - Tanggal listing di BEI

Sumber: Taliyang (2011)

\section{b. Variabel Dependen}

Variabel dependen yang digunakan dalam penelitian ini adalah sebagai berikut:

\section{Human Resource Accounting Disclosure}

Pengukuran Human Resource Accounting Disclosure dihitung menggunakan Human Resource Accounting Disclosure Index (HRADI) yang terdiri dari 26 item pengungkapan. Dalam memeriksa HRADI digunakan pendekatan dikotonomi, dimana setiap item diberi skor 1 jika diungkapkan dan diberi skor 0 jika tidak diungkapkan. Perhitungan untuk indeks Human Resource Accounting Disclosure ditentukan dengan rumus sebagai berikut:

$$
\text { HRDI }=\frac{\text { Jumlah item yang diungkapkan }}{\text { Jumlah îtem maksîmum }}
$$

Sumber: Wardini dan Muktiyano (2010)
Berikut 26 item Human Resource Accounting Disclosure Index (HRADI)

\begin{tabular}{|c|l|}
\multicolumn{2}{|l}{ Item Pengungkapan Akuntansi SDM } \\
\hline Item & \multicolumn{1}{|c|}{ Informasi pengungkapan } \\
\hline I & Imbalan Jangka Pendek \\
\hline 1 & Gaji, upah dan tunjangan \\
\hline 2 & Cuti tahunan \\
\hline 3 & Insentif \\
\hline 4 & Tunjangan produktivitas, uang jas, dan \\
& tantiem \\
\hline 5 & Bonus tahunan \\
\hline 6 & Manfaat jangka pendek lainnya \\
\hline II & Imbalan Jangka Panjang \\
\hline 1 & Iuran pension \\
\hline 2 & Kesehatan masa pension (pasca kerja) \\
\hline 3 & Penghargaan masa bakti (Long Service Award) \\
\hline 4 & Cuti panjang \\
\hline 5 & Pensiun dini \\
\hline 6 & Manfaat masa pensiun (tunjangan hari tua) \\
\hline 7 & Manfat jangka panjang lainnya \\
\hline III & Imbalan Lainnya \\
\hline 1 & Tunjangan pajak penghasilan \\
\hline 2 & Perumahan \\
\hline 3 & Pengobatan dan kesehatan \\
\hline 4 & Honorarium jasa professional \\
\hline 5 & Pendidikan, pelatihan dan pengembangan \\
\hline 6 & Pesangon PHK \\
\hline 7 & Program bonus \\
\hline 8 & Program saham untuk karyawan \\
\hline 9 & Program opsi setara saham \\
\hline 10 & Pinjaman karyawan \\
\hline 11 & Kompensasi untuk dewan direksi \\
\hline 12 & Asuransi penyandang cacat \\
\hline 13 & Tunjangan anak \\
\hline & \\
\hline
\end{tabular}

\section{Metode Analisis Data}

Untuk mengolah data sekunder yang didapatkan, penulis menggunakan bantuan software Eviews 9.0 untuk melakukan pengujian dengan analisis regresi data panel. Adapun metode analisis data yang digunakan dalam penelitian ini terdiri dari:

\section{Analisis Statistik Deskriptif}

Statistik deskriptif dalam penelitian pada dasarnya merupakan proses transformasi data penelitian dalam bentuk tabulasi, sehingga mudah dipahami dan diinterpretasikan. Deskripsi data statistik terdiri dari mean, median, maximum, minimum, standard deviation, skewness, kurtosis, Jarque-Bera, dan probability (Winarno, 2015). 


\section{Estimasi Model Regresi Data Panel}

1. Model Common Effect

Analisis model ordinary least square (OLS) atau common effect merupakan teknik yang paling sederhana mengasumsikan bahwa data gabungan yang ada menunjukkan kondisi yang sesungguhnya. Hasil analisis regresi dianggap berlaku pada semua objek pada semua waktu (Winarno, 2015).

\section{Model Fixed Effect}

Menurut Winarno (2015) diperlukan suatu model yang dapat menunjukkan perbedaan konstanta antar objek, meskipun dengan koefisien regresor yang sama. Model ini dikenal dengan nama model efek tetap atau fixed effect (Winarno, 2015).

\section{Model Random Effect}

Efek random digunakan untuk mengatasi kelemahan metode efek tetap yang menggunakan variabel semu, sehingga model mengalami ketidakpastian. Tanpa menggunakan variabel semu, metode efek random menggunakan residual, yang diduga memiliki hubungan antar waktu dan antar objek (Winarno, 2015).

\section{Pemilihan Model Regresi Data Panel}

Untuk menentukan model regresi data panel yang tepat untuk digunakan dalam analisis regresi data panel, maka kita dapat melakukan pengujian, sebagai berikut:

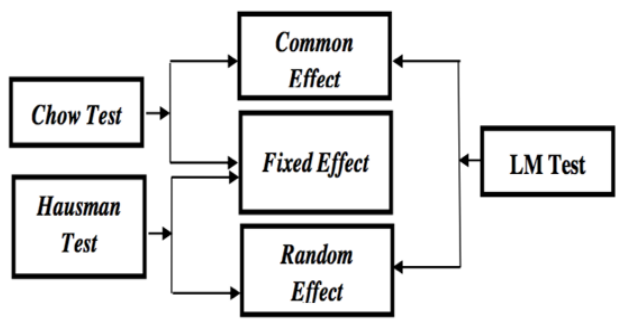

\section{Uji Hipotesis}

\section{Uji Model (Uji F)}

Uji $F$ digunakan untuk melihat apakah variabel independen secara bersama-sama mempengaruhi variabel dependen (Rizkiningsih, 2012).Hipotesis dalam penelitian ini dirumuskan sebagai berikut:

$\mathrm{H}_{0}$ : Ukuran perusahaan, leverage, profitabilitas, dan umur perusahaan secara bersama-sama tidak berpengaruh terhadap Human Resource Accounting Disclosure.

$\mathrm{H}_{\mathrm{a}}$ : Ukuran perusahaan, leverage, profitabilitas, dan umur perusahaan secara bersama-sama berpengaruh terhadap Human Resource Accounting Disclosure.

\section{Koefisien Determinasi $\left(\mathbf{R}^{\mathbf{2}}\right)$}

Koefisien Determinasi $\left(\mathrm{R}^{2}\right)$ digunakan untuk melihat berapa presentase pengaruh variabel independen terhadap variabel dependen (Priyatno, 2012). Peneliti menggunakan Adjusted $R$ Square yang merupakan nilai $R$ Square yang telah disesuaikan. Untuk regresi dengan lebih dari dua variabel independen digunakan Adjusted $R$ Square sebagai koefisien determinasi (Priyatno, 2012).

\section{Uji t}

Uji $\mathrm{t}$ dilakukan untuk melihat pengaruh secara parsial variabel independen terhadap variabel dependen (Rizkiningsih, 2012). Hipotesis dalam penelitian ini dirumuskan sebagai berikut:

a) Ukuran Perusahaan

$\mathrm{H}_{0}$ : Ukuran perusahaan tidak berpengaruh terhadap Human Resource Accounting Disclosure.

$\mathrm{H}_{1}$ : Ukuran perusahaan berpengaruh terhadap Human Resource Accounting Disclosure.

b) Leverage

$\mathrm{H}_{0}$ : Leverage tidak berpengaruh terhadap Human Resource Accounting Disclosure.

$\mathrm{H}_{2}$ : Leverage berpengaruh terhadap Human Resource Accounting Disclosure.

c) Profitabilitas

$\mathrm{H}_{0}$ : Profitabilitas tidak berpengaruh terhadap Human Resource Accounting Disclosure.

$\mathrm{H}_{3}$ : Profitabilitas berpengaruh terhadap Human Resource Accounting Disclosure. 
d) Umur Perusahaan

$\mathrm{H}_{0}$ : Umur perusahaan tidak berpengaruh terhadap Human Resource Accounting Disclosure.

$\mathrm{H}_{4}$ : Umur perusahaan berpengaruh terhadap Human Resource Accounting Disclosure.

\section{Kerangka Konseptual}

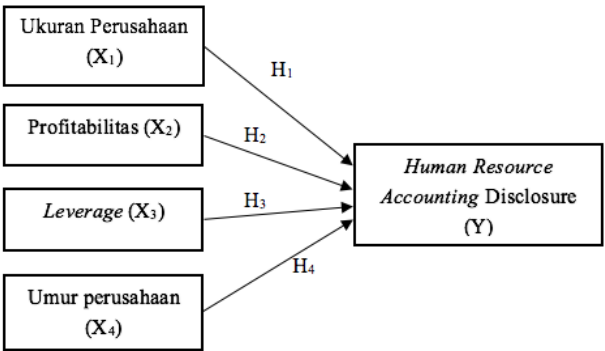

\section{Analisis Regresi Data Panel}

Data panel merupakan gabungan antara data time series dan data cross section (Winarno, 2015). Data time series merupakan data yang terdiri atas satu objek namun meliputi beberapa periode waktu, sedangkan data cross section merupakan data yang terdiri atas beberapa objek pada suatu waktu (Winarno, 2015). Berikut persamaan regresi dalam penelitian ini:

$$
\begin{aligned}
Y_{\text {it }}= & \beta_{0}+\beta_{1} X 1_{\text {it }}+\beta_{2} X 2_{\text {it }}+\beta_{2} X 3_{\text {it }} \\
& +\beta_{3} X 4_{\text {it }}+\theta_{\text {it }}
\end{aligned}
$$

Keterangan:

$\mathrm{Y}_{\mathrm{it}} \quad=$ Human Resource Accounting

$$
\text { Disclosure }
$$

$\beta_{0}=$ Konstanta

$\mathrm{X}_{\text {it }}=$ Ukuran Perusahaan

$\mathrm{X} 2_{\text {it }}=$ Profitabilitas

$\mathrm{X}_{\text {it }}=$ Leverage

$\mathrm{X} 4_{\text {it }}=$ Umur Perusahaan

$\mathrm{e}_{\mathrm{it}}=$ Komponen eror

\section{Hasil Penelitian dan Pembahasan}

Analisis Statistik Deskriptif

\begin{tabular}{|l|c|c|c|c|c|}
\hline & HRAD & SIZE & ROA & DAR & AGE \\
\hline Mean & 0.339944 & 28.68027 & 0.080981 & 0.425099 & 20.57021 \\
\hline Median & 0.346154 & 28.52476 & 0.057642 & 0.389439 & 23.81781 \\
\hline Maximum & 0.615385 & 33.47373 & 0.526704 & 2.055781 & 36.99452 \\
\hline Minimum & 0.115385 & 25.21557 & 0.000282 & 0.076894 & 0.257534 \\
\hline Std. Dev. & 0.126127 & 1.606039 & 0.085444 & 0.263097 & 9.228741 \\
\hline Skewness & 0.258809 & 0.515485 & 2.636863 & 3.016401 & -0.850293 \\
\hline Kurtosis & 2.236545 & 3.177321 & 11.40554 & 18.37380 & 2.701785 \\
\hline & & & & & \\
\hline Jarque-Bera & 6.806335 & 8.754746 & 787.7224 & 2181.987 & 23.84740 \\
\hline Probability & 0.033268 & 0.012558 & 0.000000 & 0.000000 & 0.000007 \\
\hline & & & & & \\
\hline Sum & 65.26923 & 5506.612 & 15.54841 & 81.61905 & 3949.479 \\
\hline Sum Sq. Dev. & 3.038454 & 492.6583 & 1.394443 & 13.22100 & 16267.40 \\
\hline & & & & & \\
\hline Observations & 192 & 192 & 192 & 192 & 192 \\
\hline
\end{tabular}

Pada tabel di atas, dapat dijelaskan bahwa jumlah data (observations) yang digunakan dalam penelitian ini sebanyak 192 data.

\section{Variabel Human Resource Accounting Disclosure (HRAD)}

Memiliki nilai minimum sebesar 0.115385 , sedangkan untuk nilai maksimumnya sebesar 0.615385. Hasil tersebut menunjukkan bahwa nilai HRAD pada perusahaan manufaktur yang menjadi objek penelitian berkisar antara 0.115385 sampai 0.615385 dengan nilai rata-rata 0.339944 dan Standar Deviasi 0.126127. Nilai HRAD tertinggi pada PT Indocement Tunggal Prakarsa Tbk yaitu 0.615385 sedangkan nilai terendah pada perusahaan PT Trias Sentosa Tbk yaitu 0.115385 .

Variabel Ukuran Perusahaan (SIZE) Memiliki nilai minimum sebesar 25.21557, sedangkan untuk nilai maksimumnya sebesar 33.47373. Hasil tersebut menunjukkan bahwa nilai ukuran perusahaan pada perusahaan manufaktur yang menjadi objek penelitian berkisar antara 25.21557 sampai 33.47373 dengan nilai rata-rata 28.68027 dan Standar Deviasi 1.606039. Nilai SIZE tertinggi pada PT Astra International Tbk pada tahun 2018 yaitu 33.47373 sedangkan nilai terendah pada perusahaan PT Primarindo Asia 
Infrastucture Tbk pada tahun 2017 yaitu 25.21557 .

\section{Variabel Profitabilitas (ROA)}

Memiliki nilai minimum sebesar 0.000282 , sedangkan untuk nilai maksimumnya sebesar 0.526705. Hasil tersebut menunjukkan bahwa nilai profitabilitas pada perusahaan manufaktur yang menjadi objek penelitian berkisar antara 0.000282 sampai 0.526705 dengan nilai rata-rata 0.080981 dan Standar Deviasi 0.085444. Nilai ROA tertinggi pada PT Multi Bintang Indonesia Tbk pada tahun 2017 yaitu 0.526705 sedangkan nilai terendah pada perusahaan PT Star Petrochem Tbk pada tahun 2018 yaitu 0.000282 .

\section{Variabel Leverage (DAR)}

Memiliki nilai minimum sebesar 0.076894, sedangkan untuk nilai maksimumnya sebesar 2.055781. Hasil tersebut menunjukkan bahwa nilai leverage perusahaan manufaktur yang menjadi objek penelitian berkisar antara 0.076894 sampai 2.055781 dengan nilai rata-rata 0.425099 dan Standar Deviasi 0.263097. Nilai DAR tertinggi pada PT Primarindo Asia Infrastructure Tbk pada tahun 2016 yaitu 2.055781 sedangkan nilai terendah pada perusahaan PT Industri Jamu dan Farmasi Sido Muncul Tbk pada tahun 2016 yaitu 0.076894 .

Variabel Umur Perusahaan (AGE) Memiliki nilai minimum sebesar 0.257534, sedangkan untuk nilai maksimumnya sebesar 36.99452. Hasil tersebut menunjukkan bahwa nilai umur perusahaan pada perusahaan manufaktur yang menjadi objek penelitian berkisar antara 0.257534 sampai 36.99452 dengan nilai rata-rata 20.57021 dan Standar Deviasi 9.228741. Nilai AGE tertinggi pada PT Unilever Indonesia Tbk pada tahun 2018 yaitu 36.99452 sedangkan nilai terendah pada perusahaan PT Aneka Gas Industri Tbk pada tahun 2016 yaitu 0.257534 .

\section{Pemilihan Model Regresi Data Panel Uji Chow}

Uji Chow digunakan untuk memilih model yang digunakan, apakah sebaiknya menggunakan Common Effect Model (CEM) atau Fixed Effect Model (FEM).

Kriteria dalam pengujian ini jika nilai probabilitas (Prob.) cross section $\mathrm{F}$ dan cross-section chi-square $>\alpha(0,05)$ maka model yang digunakan adalah common effect model. Namun, jika (Prob.) cross section $\mathrm{F}$ dan cross-section chi-square $<\alpha$ $(0,05)$ maka model yang digunakan adalah fixed effect model. Adapun hasil Uji Chow terlihat pada tabel berikut ini:

\begin{tabular}{|lrrr|}
\hline \begin{tabular}{l} 
Redundant Fixed Effects Tests \\
Equation: EQ01 \\
Test cross-section fixed effects \\
\hline \hline Effects Test
\end{tabular} & Statistic & d.f. & Prob. \\
\hline \hline Cross-section F & 198.855226 & $(63,124)$ & 0.0000 \\
Cross-section Chi-square & 888.053659 & 63 & 0.0000 \\
\hline \hline
\end{tabular}

Berdasarkan tabel diatas, nilai Probabilitas (Prob.) cross-section F 0,0000 < 0,05 dan cross-section chi-square sebesar 0,0000 < 0,05 maka dapat disimpulkan bahwa Fixed Effect Model (FEM) lebih layak digunakan dibandingkan Common Effect Model (CEM).

\section{Uji Hausman}

Uji Hausman digunakan untuk memilih model yang digunakan apakah sebaiknya menggunakan Random Effect Model (REM) atau Fixed Effect Model (FEM). Pengujian ini dapat dilihat pada nilai Probabilitas (Prob.) cross-section random.Kriteria dalam pengujian ini jika nilai probabilitas (Prob.) cross section random $>\alpha(0,05)$ maka model yang digunakan adalah random effect model. Namun, jika (Prob.) cross section random $<\alpha(0,05)$ maka model yang digunakan adalah fixed effect model.Adapun hasil Uji Hausman adalah sebagai berikut:

\begin{tabular}{|lccc|}
\hline $\begin{array}{l}\text { Correlated Random Effects - Hausman Test } \\
\text { Equation: EQ01 } \\
\text { Test cross-section random effects }\end{array}$ & & \\
\hline \hline Test Summary & Chi-Sq. Statistic & Chi-Sq. d.f. & Prob. \\
\hline \hline Cross-section random & 4.582890 & 4 & 0.3328 \\
\hline
\end{tabular}


Berdasarkan tabel diatas, nilai Probabilitas (Prob.) cross-section random sebesar $0,3328>0,05$. Maka dapat disimpulkan bahwa Random Effect Model (REM)lebih layak digunakan dibandingkan Fixed Effect Model (FEM).

\section{Uji Lagrange Multiplier}

Uji Lagrange Multiplier digunakan untuk memilih model yang digunakan apakah sebaiknya menggunakan Random Effect Model (REM) atau Common Effect Model (CEM). Pengujian ini dapat dilihat pada nilai Probabilitas Breush-pagan.Kriteria dalam pengujian ini jika nilai Probabilitas cross-section Breush-pagan > $\alpha(0,05)$ maka model yang digunakan adalah Common Effect Model (CEM). Sedangkan jika nilai Probabilitas crosssection Breush-pagan $<\alpha(0,05)$ maka maka model yang digunakan adalah Random Effect Model (REM). Adapun hasil uji Lagrange Multiplier terlihat pada tabel berikut ini:

\begin{tabular}{|c|c|c|c|}
\hline \multicolumn{4}{|c|}{$\begin{array}{l}\text { Lagrange Multiplier Tests for Random Effects } \\
\text { Null hypotheses: No effects } \\
\text { Alternative hypotheses: Two-sided (Breusch-Pagan) and one-sided } \\
\text { (all others) alternatives }\end{array}$} \\
\hline & \multicolumn{3}{|c|}{ Test Hypothesis } \\
\hline Breusch-Pagan & $\begin{array}{l}185.6306 \\
(0.0000)\end{array}$ & $\begin{array}{l}1.494465 \\
(0.2215)\end{array}$ & $\begin{array}{l}187.1250 \\
(0.0000)\end{array}$ \\
\hline
\end{tabular}

Berdasarkan tabel diatas, nilai Probabilitas cross-section Breusch-pagan sebesar $0,0000<0,05$. Maka dapat disimpulkan bahwa Random Effect Model (REM) lebih layak digunakan dibandingkan Common Effect Model (CEM).

Berdasarkan pengujian terhadap ketiga model regresi data panel, berikut kesimpulan hasil pengujian pemilihan model regresi data panel:

\begin{tabular}{|c|l|c|c|}
\hline No & \multicolumn{1}{|c|}{ Metode } & Pengujian & Hasil \\
\hline 1 & Uji Chow & CEM vs FEM & FEM \\
\hline 2 & Uji Hausman & FEM vs REM & REM \\
\hline 3 & Uji LM & CEM vs REM & REM \\
\hline
\end{tabular}

Maka dapat disimpulkan bahwa model Random Effect akan digunakan lebih lanjut dalam mengestimasi pengaruh ukuran perusahaan, profitabilitas, leverage, dan umur perusahaan terhadap Human Resource Accounting Disclosure (HRAD). Adapun Random Effect Model (REM) adalah sebagai berikut:

\begin{tabular}{|c|c|c|c|c|}
\hline \multicolumn{5}{|c|}{$\begin{array}{l}\text { Dependent Variable: HRAD } \\
\text { Method: Panel EGLS (Cross-section random effects) } \\
\text { Date: } 09 / 29 / 19 \text { Time: } 02: 41 \\
\text { Sample: } 20162018 \\
\text { Periods included: } 3 \\
\text { Cross-sections included: } 64 \\
\text { Total panel (balanced) observations: } 192 \\
\text { Swamy and Arora estimator of component variances }\end{array}$} \\
\hline Variable & Coefficient & Std. Error & t-Statistic & Prob. \\
\hline $\begin{array}{l}\text { C } \\
\text { SIZE } \\
\text { ROA } \\
\text { DAR } \\
\text { AGE }\end{array}$ & $\begin{array}{r}-0.233952 \\
0.019768 \\
0.173700 \\
0.000129 \\
-0.000349\end{array}$ & $\begin{array}{l}0.167890 \\
0.006156 \\
0.044570 \\
0.020449 \\
0.001062\end{array}$ & $\begin{array}{r}-1.393484 \\
3.211066 \\
3.897253 \\
0.006302 \\
-0.328929\end{array}$ & $\begin{array}{l}0.1651 \\
0.0016 \\
0.0001 \\
0.9950 \\
0.7426\end{array}$ \\
\hline \multicolumn{5}{|c|}{ Effects Specification } \\
\hline $\begin{array}{l}\text { Cross-section random } \\
\text { Idiosyncratic random }\end{array}$ & & & $\begin{array}{l}0.114708 \\
0.013676 \\
\end{array}$ & $\begin{array}{l}0.9860 \\
0.0140\end{array}$ \\
\hline \multicolumn{5}{|c|}{ Weighted Statistics } \\
\hline $\begin{array}{l}\text { R-squared } \\
\text { Adjusted R-squared } \\
\text { S.E. of regression } \\
\text { F-statistic } \\
\text { Prob(F-statistic) }\end{array}$ & $\begin{array}{l}0.119545 \\
0.100712 \\
0.013698 \\
6.347541 \\
0.000082 \\
\end{array}$ & $\begin{array}{l}\text { Mean dep } \\
\text { S.D. depe } \\
\text { Sum squa } \\
\text { Durbin-W }\end{array}$ & $\begin{array}{l}\text { endent var } \\
\text { ndent var } \\
\text { red resid } \\
\text { latson stat }\end{array}$ & $\begin{array}{l}0.023345 \\
0.014444 \\
0.035086 \\
1.694593\end{array}$ \\
\hline \multicolumn{5}{|c|}{ Unweighted Statistics } \\
\hline $\begin{array}{l}\text { R-squared } \\
\text { Sum squared resid }\end{array}$ & $\begin{array}{l}0.185557 \\
2.474647\end{array}$ & $\begin{array}{l}\text { Mean de } \\
\text { Durbin-V }\end{array}$ & $\begin{array}{l}\text { endent var } \\
\text { atson stat }\end{array}$ & $\begin{array}{l}0.339944 \\
0.024026\end{array}$ \\
\hline
\end{tabular}

\section{Uji Hipotesis}

\section{Uji Kelayakan Model}

\begin{tabular}{llll} 
& \multicolumn{4}{l}{ Hasil Uji Model (Uji F) } & \\
\hline R-squared & 0.119545 & Mean dependent var & 0.023345 \\
Adjusted R-squared & 0.100712 & S.D. dependent var & 0.014444 \\
S.E. of regression & 0.013698 & Sum squared resid & 0.035086 \\
F-statistic & 6.347541 & Durbin-Watson stat & 1.694593 \\
Prob(F-statistic) & 0.000082 & & \\
\hline
\end{tabular}

Tabel hasil uji $\mathrm{F}$ menunjukkan bahwa nilai F-statistic sebesar 6,347541 sementara $\mathrm{F}$ Tabel dengan tingkat $\alpha=5 \%, \mathrm{df} 1(\mathrm{k}-1)=4$ dan df $2(n-k)=187$ didapat nilai $F$ Tabel sebesar 2,42. dengan demikian F-statistic $(6,347541)>$ F Tabel $(2,42)$ dan nilai Prob (F- statistic) $0.000082<0,05$ maka dapat disimpulkan bahwa Ha diterima, maka dengan demikian dapat disimpulkan bahwa variabel-variabel independen dalam penelitian ini yang terdiri dari ukuran perusahaan (SIZE), profitabilitas (ROA), leverage (DAR) dan umur perusahaan (AGE) secara bersama-sama memiliki 
pengaruh terhadap Human Resource Accounting Disclosure (HRAD).

\section{Koefisien Determinasi}

\begin{tabular}{llll}
\multicolumn{4}{c}{ Hasil Koefisien Determinasi } \\
\hline \hline R-squared & 0.119545 & Mean dependent var & 0.023345 \\
Adjusted R-squared & 0.100712 & S.D. dependent var & 0.014444 \\
S.E. of regression & 0.013698 & Sum squared resid & 0.035086 \\
F-statistic & 6.347541 & Durbin-Watson stat & 1.694593 \\
Prob(F-statistic) & 0.000082 & & \\
\hline
\end{tabular}

Berdasarkan tabel diatas nilai adjusted $R$ squared sebesar 0.100712, artinya bahwa variasi perubahan naik turunnya Human Resource Accounting Disclosure (HRAD) dapat dijelaskan oleh ukuran perusahaan (SIZE), profitabilitas (ROA), leverage (DAR) dan umur perusahaan (AGE) sebesar $10,07 \%$, sementara sisanya yaitu sebesar $89,93 \%$ dijelaskan oleh variabel-variabel lain yang tidak diteliti dalam penelitian ini.

Uji t

\begin{tabular}{crrrr}
\hline \multicolumn{5}{c}{ Hasil Uji t (Uji Hipotesis) } \\
\hline \hline Variable & Coefficient & Std. Error & t-Statistic & Prob. \\
\hline \hline C & -0.233952 & 0.167890 & -1.393484 & 0.1651 \\
SIZE & 0.019768 & 0.006156 & 3.211066 & 0.0016 \\
ROA & 0.173700 & 0.044570 & 3.897253 & 0.0001 \\
DAR & 0.000129 & 0.020449 & 0.006302 & 0.9950 \\
AGE & -0.000349 & 0.001062 & -0.328929 & 0.7426 \\
\hline \hline
\end{tabular}

\section{Pembahasan}

\section{Pengaruh Ukuran Perusahaan (Size) Terhadap Human Resource Accounting Disclosure}

Variabel ukuran perusahaan (SIZE) memiliki nilai t-statistic sebesar 3,211066, sedangkan nilai t Tabel dengan tingkat $\alpha=$ $5 \%$, df $(\mathrm{n}-\mathrm{k})=187$ didapat $\mathrm{t}$ Tabel sebesar 1,97273. Dengan demikian t-statistic ukuran perusahaan (SIZE) $(3,211066)>\mathrm{t}$ Tabel $(1,97273)$ dan nilai Prob. 0,0016 < 0,05. Berdasarkan hasil tersebut, maka dapat disimpulkan bahwa variabel ukuran perusahaan dalam penelitian ini memiliki pengaruh terhadap Human Resource Accounting Disclosure. Hasil penelitian ini sejalan dengan penelitian Santioso (2017) yang menyatakan bahwa ukuran perusahaan berpengaruh positif terhadap Human Resource Accounting Disclosure .

Berdasarkan data penelitian variabel ukuran perusahaan PT Astra Internasional Tbk memiliki nilai ukuran perusahaan tertinggi yaitu 33.47373 dengan jumlah HRAD yang cukup tinggi yaitu sebanyak 15 item pengungkapan, dan PT Primarindo Asia Infrastructure Tbk memiliki nilai ukuran perusahaan terendah yaitu 25.21557 dengan jumlah HRAD yang cukup rendah hanya terdapat 7 item pengungkapan. Hal ini menunjukkan bahwa semakin besar ukuran perusahaan semakin besar pula jumlah HRAD yang dapat diungkapkan.

Hasil penelitian ini sesuai dengan teori signal (signalling theory) yang menyatakan bahwa ukuran perusahaan yang besar menunjukkan perusahaan mengalami perkembangan sehingga akan memberikan sinyal baik kepada pihak luar seperti para investor yang memberikan respon positif dan nilai perusahaan akan meningkat. Sehingga perusahaan berukuran besar akan mengungkapkan informasi yang lebih banyak, karena mendapatkan permintaan yang lebih besar dari public dan para investor untuk mengungkapkan informasi yang lebih lengkap.

Pengaruh Profitabilitas (ROA) Terhadap Human Resource Accounting Disclosure

Variabel profitabilitas (ROA) memiliki nilai t-statistic sebesar 3,897253, sedangkan nilai $\mathrm{t}$ Tabel dengan tingkat $\alpha=5 \%$, df $(\mathrm{n}-\mathrm{k})=$ 187 didapat $t$ Tabel sebesar 1,97273. Dengan demikian t-statistic profitabilitas (ROA) $(3,897253)>$ t Tabel $(1,97273)$ dan nilai Prob. 0,0001 <0,05. Berdasarkan hasil tersebut, maka dapat disimpulkan bahwa variabel profitabilitas dalam penelitian ini memiliki pengaruh terhadap Human Resource Accounting Disclosure. Hasil penelitian ini sejalan dengan penelitian Kadek Dian Negariani (2017) yang menyatakan bahwa profitabilitas berpengaruh positif terhadap pengungkapan akuntansi SDM. 
Berdasarkan data penelitian variabel profitabilitas PT Multi Bintang Indonesia Tbk memiliki nilai profitabilitas tertinggi yaitu 0,52675 dengan jumlah HRAD yang cukup tinggi yaitu sebanyak 12 item pengungkapan, dan PT Star Petrochem Tbk memiliki nilai profitabilitas terendah yaitu 0,526705 dengan jumlah HRAD yang cukup rendah hanya terdapat 7 item pengungkapan. Hal ini menunjukkan bahwa ketika tingkat profitabilitas semakin tinggi maka akan semakin tinggi pula jumlah HRAD yang dapat diungkapkan.

Hasil penelitian ini sesuai dengan teori signal (signalling theory) yang menyatakan bahwa tingkat profitabilitas tinggi akan menggunakan informasi keuangannya untuk mengirim sinyal kepada pasar. Tingkat profitabilitas yang tinggi akan menunjukkan prospek perusahaan baik, sehingga investor akan merespon positif sinyal tersebut. Ketika mendapatkan respon pasar yang baik perusahaan akan mengungkapkan informasi mengenai SDM yang lebih luas sehingga para investor semakin yakin dengan dana yang dikelola oleh SDM yang berkompeten.

\section{Pengaruh Leverage (DAR) Terhadap Human Resource Accounting Disclosure}

Variabel leverage (DAR) memiliki nilai tstatistic sebesar 0,006302 , sedangkan nilai $\mathrm{t}$ Tabel dengan tingkat $\alpha=5 \%$, df $(\mathrm{n}-\mathrm{k})=$ 187 didapat $\mathrm{t}$ Tabel sebesar 1,97273. Dengan demikian t-statistic leverage (DAR) $(0,006302)<\mathrm{t}$ Tabel $(1,97273)$ dan nilai Prob. $0,9950>0,05$. Berdasarkan hasil tersebut, maka dapat disimpulkan bahwa variabel leverage dalam penelitian ini tidak memiliki pengaruh terhadap Human Resource Accounting Disclosure. Hasil penelitian ini sejalan dengan penelitian Isyana Ningsih Setiono dan Felizia Arni Rudiawati (2012) yang menyatakan bahwa leverage tidak berpengaruh terhadap pengungkapan akuntansi SDM.

Berdasarkan data penelitian variabel leverage PT Primarindo Asia Infrastructure
Tbk memiliki nilai leverage tertinggi yaitu 2.055781 dengan jumlah HRAD yang cukup rendah hanya terdapat 7 item pengungkapan dan PT Industri Jamu dan Farmasi Sido Muncul Tbk memiliki nilai leverage terendah yaitu 0,076894 dengan jumlah HRAD yang rendah hanya terdapat 5 item pengungkapan. Hal ini mengindikasikan bahwa tinggi atau rendahnya tingkat hutang perusahaan tidak mempengaruhi luasnya perusahaan dalam mengungkapkan informasi SDM perusahaan. Perusahaan dengan tingkat hutang yang tinggi cenderung lebih sedikit atau tidak dapat maksimal dalam mengungkapkan informasi Human Resource Accounting Disclosure karena lebih fokus membayar hutang perusahaan.

Hasil penelitian ini tidak sesuai dengan teori keagenan (agency theory) yang menyatakan bahwa perusahaan dengan tingkat hutang yang lebih tinggi akan mengungkapkan lebih banyak informasi, karena biaya keagenan dengan struktur modal seperti itu lebih tinggi. sehingga semakin tingginya tingkat hutang akan mendorong peningkatan pengungkapan SDM perusahaan.

\section{Pengaruh Umur Perusahaan (AGE) Terhadap Human Resource Accounting Disclosure}

Variabel Umur perusahaan (AGE) memiliki nilai t-statistic sebesar -0,328929, sedangkan nilai $\mathrm{t}$ Tabel dengan tingkat $\alpha=$ $5 \%$, df $(\mathrm{n}-\mathrm{k})=187$ didapat $\mathrm{t}$ Tabel sebesar 1,97273. Dengan demikian t-statistic Umur perusahaan (AGE) $(-0,328929)<\mathrm{t}$ Tabel $(1,97273)$ dan nilai Prob. 0,7426>0,05. Berdasarkan hasil tersebut, maka dapat disimpulkan bahwa variabel umur perusahaan dalam penelitian ini tidak memiliki pengaruh terhadap Human Resource Accounting Disclosure.Hasil penelitian ini sejalan dengan penelitian Santioso (2017) yang menyatakan bahwa umur perusahaan tidak berpengaruh terhadap pengungkapan akuntansi SDM. 
Berdasarkan data penelitian variabel umur perusahaan PT Unilever Indonesia Tbk memiliki nilai umur perusahaan lebih tua yaitu 37,0 dengan jumlah HRAD yang cukup tinggi yaitu sebanyak 14 item pengungkapan, dan PT Aneka Gas Industri Tbk memiliki nilai umur perusahaan lebih muda yaitu 0,2 dengan jumlah HRAD yang cukup tinggi yaitu sebanyak 13 item pengungkapan. Hal ini menunjukkan perusahaan lebih muda mengungkapkan Human Resource Accounting Disclosure dengan jumlah yang sama besar dengan perusahaan yang lebih tua. Karena lamanya suatu perusahaan bukan merupakan faktor penentu penentu bahwa perusahaan akan mengungkapkan informasi terkait sumber daya manusia. Sehingga berapapun umur suatu perusahaan tidak menentukan bahwa perusahaan tersebut akan mengungkapkan sumber daya manusia dalam laporan keuangan perusahaan.

Hasil penelitian ini tidak sesuai dengan teori keagenan (agency theory) yang menyatakan bahwa perusahaan yang memiliki umur lebih tua cenderung lebih dipercayai oleh principal karena lebih berpengalaman dalam mengelola perusahaan tersebut. Sehingga semakin besar informasi SDM yang dapat diungkapkan.

\section{Analisis Regresi Data Panel}

$$
\begin{aligned}
\mathrm{HRAD}= & -0,233952-0,019768 \mathrm{SIZE}+ \\
& 0,173700 \mathrm{ROA}+0,000129 \mathrm{DAR} \\
& -0,000349 \mathrm{AGE}+\mathrm{e}
\end{aligned}
$$

Persamaan model regresi data panel dalam penelitian adalah sebagai berikut:

a. Nilai konstanta untuk persamaan regresi sebesar (C) 0,233952 hal ini menunjukkan jika variabel ukuran perusahaan (SIZE), profitabilitas (ROA), leverage (DAR) dan umur perusahaan (AGE) bernilai konstan atau sama dengan nol, maka Human
Resource Accounting Disclosure bernilai sebesar 0,233952 .

b. Nilai koefisien regresi ukuran perusahaan (SIZE) adalah 0,019768. Hal ini dapat diartikan setiap terjadi peningkatan nilai ukuran perusahaan (SIZE) sebesar 1 satuan maka akan berdampak pada penurunan nilai Human Resource Accounting Disclosure sebesar 0,019768 satuan. Sebaliknya setiap terjadi penurunan nilai ukuran perusahaan (SIZE) sebesar 1 satuan maka berdampak pada peningkatan nilai Human Resource Accounting Disclosure sebesar 0,019768 satuan.

c. Nilai koefisien regresi variabel profitabilitas (ROA) adalah 0,173700. Hal ini dapat diartikan setiap terjadi peningkatan nilai profitabilitas (ROA) sebesar 1 satuan maka akan berdampak pada peningkatan nilai Human Resource Accounting Disclosure sebesar 0,173700 satuan. Sebaliknya setiap terjadi penurunan nilai profitabilitas (ROA) sebesar 1 satuan maka berdampak pada penurunan nilai Human Resource Accounting Disclosure sebesar 0,173700 satuan.

d. Nilai koefisien regresi variabel leverage (DAR) adalah 0,000129. Hal ini dapat diartikan setiap terjadi peningkatan nilai leverage (DAR) sebesar 1 satuan maka akan berdampak pada penurunan nilai Human Resource Accounting Disclosure sebesar 0,000129 satuan. Sebaliknya setiap terjadi peningkatan nilai leverage (DAR) sebesar 1 satuan maka berdampak pada penurunan nilai Human Resource Accounting Disclosure sebesar 0,000129 satuan.

e. Nilai koefisien regresi variabel Umur Perusahaan (AGE) adalah 0,000349. Hal ini dapat diartikan setiap terjadi peningkatan nilai Umur Perusahaan (AGE) sebesar 1 satuan maka akan berdampak pada penurunan nilai Human Resource Accounting Disclosure sebesar 0,000349 satuan. Sebaliknya setiap terjadi penurunan nilai Umur 
Perusahaan (AGE) sebesar 1 satuan maka berdampak pada peningkatan nilai Human Resource Accounting Disclosure sebesar 0,000349 satuan.

\section{Simpulan dan Saran}

\section{Simpulan}

Simpulan dari penelitian ini adalah sebagai berikut:

a. Variabel ukuran perusahaan dalam penelitian ini memiliki pengaruh positif terhadap Human Resource Accounting Disclosure . Hasil penelitian ini sejalan dengan penelitian Santioso (2017) yang menyatakan bahwa ukuran perusahaan berpengaruh positif terhadap Human Resource Accounting Disclosure. Hal ini menunjukkan bahwa semakin besar ukuran perusahaan semakin besar pula jumlah HRAD yang dapat diungkapkan.

b. Variabel profitabilitas dalam penelitian ini memiliki pengaruh positif terhadap Human Resource Accounting Disclosure. Hasil penelitian ini sejalan dengan penelitian Negariani (2017) yang menyatakan bahwa profitabilitas berpengaruh positif terhadap Human Resource Accounting Disclosure. Hal ini menunjukkan bahwa ketika tingkat profitabilitas semakin tinggi maka akan semakin tinggi pula jumlah HRAD yang dapat diungkapkan.

c. Variable leverage dalam penelitian ini tidak memiliki pengaruh terhadap Human Resource Accounting Disclosure, hasil penelitian ini sejalan dengan penelitian Setiono dan Rudiawati (2012) yang menyatakan bahwa leverage tidak berpengaruh terhadap Human Resource Accounting Disclosure. Hal ini mengindikasikan bahwa tinggi atau rendahnya tingkat hutang perusahaan tidak mempengaruhi luasnya perusahaan dalam mengungkapkan informasi SDM perusahaan. Perusahaan dengan tingkat hutang yang tinggi cenderung lebih sedikit atau tidak dapat maksimal dalam mengungkapkan informasi Human Resource Accounting Disclosure karena lebih fokus membayar hutang perusahaan.

d. Variabel umur perusahaan dalam penelitian ini tidak memiliki pengaruh terhadap Human Resource Accounting Disclosure. Hasil penelitian ini sejalan dengan penelitian Santioso (2017) yang menyatakan bahwa umur perusahaan tidak berpengaruh terhadap Human Resource Accounting Disclosure. Hal ini menunjukkan perusahaan yang usianya lebih muda mampu mengungkapkan Human Resource Accounting Disclosure dengan jumlah yang sama besar dengan perusahaan yang lebih tua. Karena lamanya suatu perusahaan bukan merupakan faktor penentu penentu bahwa perusahaan akan mengungkapkan informasi terkait sumber daya manusia. Sehingga berapapun umur suatu perusahaan tidak menentukan bahwa perusahaan tersebut akan mengungkapkan sumber daya manusia dalam laporan keuangan perusahaan.

\section{Saran}

Saran dari penelitian ini adalah sebagai berikut:

a. Bagi Emiten/Perusahaan

Perusahaan sebaiknya terus bekerja secara profesional melakukan evaluasi berkala terhadap kinerja secara profesional melakukan evaluasi berkala terhadap kinerja masing-masing agar dapat mengendalikan faktor-faktor yang dominan yang mempengaruhi penyebab lamanya HRAD. Diharapkan juga sebaiknya lebih memperhatikan kelengkapan data kinerja perusahaan, karena hal tersebut adalah tantangan bagi perusahaan publik dan institusi yang mengawasi untuk menjamin ketersediaan data laporan keuangan yang merupakan kewajiban bagi 
perusahaan publik untuk mempublikasikan ke masyarakat sebagai pengguna laporan keuangan.

b. Bagi Investor dan Calon Investor

Bagi para investor dan calon investor sebaiknya memilih perusahaan yang memiliki tingkat HRAD yang relatif tinggi. Para investor juga harus melihat perusahaan dari segi laba dan hutangnya, sehingga dikemudian hari para investor tidak mengalami kerugian yang sangat besar.

c. Untuk Peneliti Selanjutnya

1. Menambahkan jumlah sampel yang akan digunakan dalam penelitian seperti perusahan non keuangan yang terdaftar di BEI .

2. Mengembangkan pokok-pokok pengungkapan indeks HRAD secara lebih komprehensif dengan memperhatikan karakteristik dan kondisi di Indonesia terkini agar indeks HRAD yang digunakan dapat lebih merefleksikan gambaran umum SDM Akuntansi yang ada di perusahaan Indonesia dan dapat diterapkan di Indonesia.

3. Menggunakan metode content analysis lain yang dapat mengurangi tingkat subjektifitas terhadap informasi yang disajikan oleh perusahaan dalam laporanlaporannya.

\section{Daftar Pustaka}

Aditya, H. (2015). Analisis Pengaruh Good Corporate Governance Terhadap Risk Disclosure. I n Diponegoro Journal of Accounting (Vol. 4 (4)).

Affinanda, Ade. (2015). Analisis Pengaruh Rasio Keuangan Terhadap Return Saham Perusahaan.

Agustina, C. H. (2014). Pengaruh Kompetisi, Corporate Governance, Struktur Kepemilikan Terhadap Pengungkapan Risiko. 88-100.
Asfhani, Erlisa Shinta. (2017). Pengaruh ukuran perusahaan, profitabilitas, leverage, umur perusahaan dan kepemilikan pemerintah terhadap pengungkapan intellectual capital. $3,40-61$.

Eksandy, A. (2016). Pengaruh Kualitas Audit, Ukuran Perusahaan Dan Leverage Terhadap Manajemen Laba (Studi Pada Perusahaan Manufaktur Pertambangan Serta Makanan dan Minuman di Bursa Efek Indonesia. Jurnal Comparative Ekonomi Dan Bisnis, 1(1), 64-81.

Eksandy, A. (2017). Pengaruh Carbon Accounting, Business Strategy, Dan Systematic Risk Terhadap Economic PerformancE (Studi pada Perusahaan Manufaktur yang Terdaftar di Bursa Efek Indonesia Periode 2013 - 2017). COMPETITIVE, 3(2), 79-90.

Eksandy, A. (2017). Pengaruh Leverage Terhadap Pengungkapan Islamic Social Reporting Dengan Akuntabilitas Dan Transparansi Sebagai Variabel Moderating Pada Perbankan Syariah Di Indonesia Periode 2012-2016. Competitive Jurnal Akuntansi Dan Keuangan, 2(1), 96-106.

Eksandy, A. (2017). Pengaruh Ukuran Perushaan, Solvabilitas, Profitabilitas dan Komite Audit Terhadap Audit Delay (Pada Perusahaan Properti dan Real Estate yang Terdaftar di Bursa Efek Indonesia Pada Tahun 20122015). Competitive Jurnal Akuntansi Dan Keuangan, 1(2), 1-14.

Eksandy, A. (2018). Komunikasi akuntansi untuk perusahaan dagang: dilengkapi contoh praktik penyusunan laporan keuangan menggunakan program akuntansi accurate. Fakultas Ekonomi dan Bisnis Universitas Muhammadiyah Tangerang. 
Eksandy, A. (2018). Metode penelitian akuntansi dan manajemen : dilengkapi contoh penelitian data sekunder dan data primer dengan analisis regresi data panel dan analisis regresi linear berganda. Tangerang: FEB UMT.

Eksandy, A. (2018). Pengaruh Audit Tenure, Ukuran Perusahaan, Profitabilitas, Leverage Dan Komite Audit Terhadap Manajemen Laba (Studi Pada Perusahaan Jasa Subsektor Perdagangan Besar Barang. Konferensi Akuntansi Banten 1 (KAB-1) "Peran Stakeholder Dalam Mewujudkan Laporan Keuangan Pemerintahan Daerah Yang Transparan dan Akuntabel.” IAI KAPd Banten.

Eksandy, A. (2018). Pengaruh Good Corporate Governance Terhadap Kinerja Keuangan Pada Perbankan Syari'ah Indonesia. JAK (Jurnal Akuntansi): Kajian Ilmiah Akuntansi, $5(1)$, 1. https://doi.org/10.30656/jak.v5i1.498

Eksandy, A. (2018). Pengaruh Perputaran Modal Kerja , Perputaran Piutang Dan Perputaran Kas Terhadap Profitabilitas Perusahaan ( Studi Pada Perusahaan Konstruksi Sektor Infrastruktur Di Bursa Efek Indonesia Periode 2012 - 2015 ). Jurnal Dinamika UMT, 2(2), 1-14.

Eksandy, A. (2019). Pengaruh Komisaris Independen, Komite Audit, dan Kualitas Audit terhadap Penghindaran Pajak (Tax Avoidance). Competitive Jurnal Akuntansi Dan Keuangan, 1(1), 1-20.

Eksandy, A., Frederica, D., Dwianika, A., Nusdal, J., \& Hamzah, M. Z. (2017). Company Value Determinant Implementation The Corporate Governance Of Incorporated Company Issues (Year 2014-2016 LQ45). In EMAN-AP 2017 "Environmental and Sustainability Management Acccounting for The Development of Sustainablity and
Accountanbility: "Should We Talk Beyon Number?"

Eksandy, A., Frederica, D., Dwianika, A., Nusdal, J., \& Hamzah, M. Z. (2018). The Firm's Determinant Value On Corporate Governance Implementation For Incorporated Company Issues (Year 2014-2016 LQ45). Research Gate.

Eksandy, A., \& Hakim, M. Z. (2018). Faktor-Faktor Yang Berpengaruh Terhadap Pengungkapan Islamic Social Reporting pada Perbankan Syari'ah Indonesia Periode 20112015. Jurnal Akuntansi Maranatha, 10(2), 187-198. https://doi.org/10.28932/jam.v10i2.10 84

Eksandy, A., Hakim, M. Z., \& Ekawati. (2018). Pengaruh Pendapatan Asli Daerah, Dana Alokasi Umum, dan Dana Alokasi Khusus Terhadap Belanja Modal (Pada Pemerintah Provinsi Banten Periode 2011-2015). Competitive Jurnal Akuntansi Dan Keuangan, 2(2), 85-94. Retrieved from

http://jurnal.umt.ac.id/index.php/com petitive/article/view/917/582

Eksandy, A., \& Hakim, Z. M. (2017). Pengaruh Ukuran Perusahaan, Profitabilitas, dan Leverage Terhadap Pengungkapan Islamic Social Reporting (ISR). Seminar Nasional dan The 4th Call For Syariah Paper (SANCALL) 2017 "Peran Profesi Akuntansi Dalam Penaggulangan Korupsi." (pp. 4759).

Eksandy, A., \& Heriyanto, F. (2018). Metode penelitian akuntansi dan keuangan: dilengkapi analisis regresi data panel dan logistik data panel menggunakan program EViews. Fakultas Ekonomi dan Bisnis Universitas Muhammadiyah Tangerang. 
Eksandy, A., \& Milasari, E. (2019). Pengaruh Environmental Disclosure, Kualitas Auditor Internal, Dan Kontrak Manajemen Terhadap Kualitas Laba (Pada Perusahaan Indeks Kompas 100 yang Terdaftar di Bursa Efek Indonesia Periode 20132016). Competitive Jurnal Akuntansi Dan Keuangan, 3(1), 88-113.

Harahap, Sofyan Syafri (2011), Teori Akuntansi Edisi Revisi 2011. Jakarta: Rajawali Pers.

Huebla, M. (2013). انتشار نخور الطفولة|لمبكرةو تأثير هاعلنو عيةد

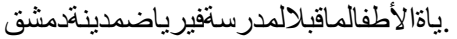
Intoxicacion As Frecuentes Y Sus Principales Factores Influyentes En Niños Atendidos En El Servicio De Pediatria Del Hospital Provincial General Docente Riobamba Periodo Enero-Agosto Del 2013, 1, 80.

Kasmir. (2015). Analisis Laporan Keuangan. Jakarta: Kencana

Jensen, Michael C. dan Meckling, William H. (1976). Theory Of Firm : Managerial Behavior, Agency Cost and Ownership Structure. Journal Of Financial Economis 3, 305-360.

Mamun, S. A. Al. (2009). Human Resource Accounting Disclosure Accounting (HRA) Disclosure of Bangladeshi Companies and Its Association With Corporate Characteristics. BRAC University Journal, 1(1), 35-43.

Negariani, K. D., Purnamawati, I. G. A., \& Kurniawan, P. S. (2017). Pengaruh Struktur Kepemilikan, Leverage , Profitabilitas Dan Return On Equity Terhadap Pengungkapan Human Resource Accounting Disclosure Accounting Pada Perusahaan Manufaktur Yang Terdaftar Di Bei Tahun 20132016.

Prapaska, J. R. (2012). Analisis Pengaruh Tingkat Profitabilitas, Keputusan Investasi, Keputusan Pendanaan, dan Kebijakan Dividen Terhadap Nilai Perusahaan Pada Perusahaan Manufaktur Di Bei Tahun 20092010.

Prastika, gilang elly. (2018). Program studi akuntansi fakultas ekonomi dan bisnis universitas muhammadiyah surakarta 2016. 15.

Ross, Stephen A. (1977). The determination of financial structure; the incentive-signalling approach.

Santioso, L., Alverianti, A., \& Daryatno, A. B. (2017). Human Resource Accounting Disclosure. Jurnal Akuntansi, 17(2), 111-124.

Setiono, I. N., \& Rudiawarni, F. A. (2012). Analisis pengaruh karakteristik perusahaan terhadap Human Capital Disclosure Pada Perusahaan High IC Intensive Industries yang Terdaftar di BEI Periode 2009-2011. Jurnal Ilmiah Mahasiswa Universitas Surabaya Vol.1, 1(1), 1-15.

Sugiyono. (2013). Metode Penelitian. Bandung: Alfabeta.

Ulfa, Maria. (2016). Pengaruh Karakteristik Perusahaan Terhadap Human Resource Accounting Disclosure (Studi Empiris Pada Perusahaan Sektor Keuangan, IT, dan Farmasi Terdaftar Bursa Efek Indonesia Tahun 2013 dan 2014).

Wardini, A. K., \& Muktiyanto, A. (2010). Pengungkapan Biaya-Biaya Tenaga Kerja Dalam Laporan Keuangan Perusahaan Go Publik Di Bursa Efek Indonesia (Idx).

Wibisono, M. (2016). Faktor-Faktor Yang Mempengaruhi Luas Human Resource Accounting Disclosure.

Widjaja, Amin (1995). Human Resource Accounting Disclosure. Jakarta: Rineka Cipta

Widodo. (2014). Pengaruh karakteristik perusahaan terhadap Human Resource Accounting Disclosure. 
Widodo, N. M., \& Widagdo, A. K. (2014). Struktur Kepemilikan Terhadap Human Resource Accounting Disclosure. Prosiding Simposium Nasional Akuntansi Mataram Lombok, 17(19).

http://www.kompasiana.com/agungbinmadi $\mathrm{k} / 569460178 \mathrm{f} 7 \mathrm{e} 611205809 \mathrm{bcd} / \mathrm{kes}$ alahan-pekerjaan-kantor 